\title{
Attitude of School Principals, Supervisors and Mentees towards Action Research as Reflective Practices
}

\section{Gemechu Abera Gobena}

Asst. Prof., Haramaya University, College of Education and Behavioural Sciences, Department of Psychology, Ethiopia, gemechu46@yahoo.com

This study was aimed to investigate the attitude of principals, supervisors and mentees towards action research as reflective practices in Postgraduate Diploma in Secondary School Teaching (PGDT). The samples used for this study consisted of 82 mentees, 38 Principals and 26 Supervisors taken from three clustered centres by using stratified random sampling technique for mentees and principals whereas availability sampling techniques were employed for supervisors. To make the interpretation of data sound and to the point, the researcher used descriptive statistics (mean scores and standard deviations) to describe the nature of the data and the characteristics of the sample. Moreover, inferential statistics (one way ANOVA) was employed to compare a significant mean differences exist between and within groups of the most likely value of the variables. The findings from this study revealed a statistically significance mean difference among mentees for lack of innovative methodologies, lack of instructional materials and lack of dedication from lecturers and attitudes towards action research as reflective practices in the case of Haramaya clustered centre. Therefore, principals and supervisors of the implementing unit of the system should act morally, practically, professionally, ethically, responsibly and critically so as to accommodate professional need of the nation to bring behavioural changes and quality education for the Ethiopian children.

Key Words: attitudes, Haramaya University, psychology, Ethiopian children, school principals, reflective practices

\section{INTRODUCTION}

In the last decade, the slogans of reflective teaching, action research, research based and inquiry-oriented teacher education have been embraced by both teacher- educators and educational researchers throughout the world (Schuck and Wood 2006). On the one hand, teacher educators who represent a variety of conceptual and ideological orientations to schooling and teacher education, have, under the umbrella of reflective practice, tried to prepare teachers who are more thoughtful and analytic about their work in some fashion. On the other hand, educational researchers, including researchers 
identified with the research on teacher-thinking movement, have attempted to document and describe the processes of teacher reflection and associated actions, and the relationship between these processes and teacher development (La Boskey, 1990; Russell and Munby, 1991). Other researchers have focused on studying the social and individual conditions which influence the reflections of teachers (Erickson and Mackinnon, 1991; Grimmett and Crehan, 1990; Zeichner, 1998; and Gemechu, 2014).

Interestingly, the reasons that initiated the Teacher Education System Overhaul (TESO) reform in Ethiopia thirteen years ago were very much similar to the current problems that characterize teacher education. For example, in introducing Teacher Education System Overhaul (TESO), it was remembered that Ministry of Education (MoE, 2003) in Teshome (2001) outlined the following causes: (1) the professional competence of teachers is deficient, (2) the content knowledge of teachers is unsatisfactory, (3) the teaching skills and techniques are very basic, (4) teachers do not match up to the standards and expectations of their professions, (5) practicum receives inadequate emphasis and is insufficiently implemented, (6) the quality of courses and methods of teaching are theoretical and teacher centred, (7) there is lack of professionalism, and ethical values in Ethiopian teacher education program

Consequently, it is reasonably common for preservice courses to be designed by predominantly gain so as to accommodate problems that have already been mentioned. As a result, student-teachers are often not introduced to educational research in general and action research as reflective practices in particular. Therefore, the researcher attempted to fill the existed gap so that the attitudes of student-teachers, principals and supervisors would be improved to increase the attitudes of these stakeholders towards action research as reflective practices.

\section{THE CONCEPT AND IMPLICATIONS OF ACTION RESEARCH}

Action research is a process in which participants examine their own educational practice systematically and carefully, using the techniques of research (Gemechu, 2014). It is based on the following assumptions: (1) Teachers and principals work best on problems they have identified for themselves. (2) Teachers and principals become more effective when encouraged to examine and assess their own work and then consider ways of working differently. (3)Teachers and principals help each other by working collaboratively. (4) Working with colleagues helps teachers and principals in their professional development (Watts, 1985).

An analysis of these teachers' education efforts revealed instructional strategies that tend to characterize reflective practices were: action research, ethnography, writing and reflection, supervision and reflective teaching, curriculum development and analysis (Valii, 1992). Moreover, Zeichner (1987) provides a useful review of the use of action research in teacher education and the kinds of changes in teachers' perception which are believed to be affected by student teachers' involvement in such research. These changes include: (1) a different conception of the teacher role; (2) increasing self-confidence; (3) changes in stages of concern; (4) increasing awareness of classroom events; (5) attaining positive disposition towards reflection; (6) changes in specific educational beliefs; (7) 
increasing the congruence between theory and practice; and (8) broadening of teachers' views of teaching, schooling and society.

\section{Reflective Practice and Professional Development}

Reflective practice can be a beneficial process in teacher professional development for both pre-service and in-service teachers. According to Schon (1987) who introduced the concept of reflective practice as a critical process, he tried to refine one's artistry or craft in a specific discipline. He recommended reflective practice as a way for beginners in a discipline to recognize consonance between their own individual practices and those of successful practitioners. As defined by him, reflective practice involves thoughtfully considering one's own experiences in applying knowledge to practice while being coached by professionals in the discipline. After the concept of reflective practice was introduced by Schon, many schools, colleges, and departments of education began designing teacher education and professional development programs based on this concept. As the concept grew in popularity, some researchers cautioned that SCDEs that incorporated reflective practice in their teacher education programs were focusing on the process of reflective practice while sacrificing important content in teacher education (Clift et al, 1990).

These researchers recommended that reflective teaching combine John Dewey's philosophy on the moral, situational aspects of teaching with Schon's process for a more contextual approach to the concept of reflective practice. He took issue with what they considered to be a checklist or reflection on demand mentality, reflection processes with no link to conceptual frameworks, a failure to encourage students to challenge teaching practices, and a need for personal disclosure that was beyond the capacity of some young teachers. Bound and Walker (1998) suggest that these weaknesses can be addressed when the teacher-coaches create an environment of trust and build a context for reflect- on unique to every learning situation. Reflective practice has also been defined in terms of action research. Action research, in turn, is defined as a tool of curriculum development consisting of continuous feedback that targets specific problems in a particular school setting (Hopkins \& Antes, 1990).

\section{Incorporating reflection into practice}

Reflective practice is used at both the pre-service and in-service levels of teaching. Coaching and peer involvement are the two aspects of reflective practice seen most often at the pre-service level. Teacher educators can most effectively coach student teachers in reflective practice by using students' personal histories, dialogue journals, and small and large-group discussions about their experiences to help students reflect upon and improve their practices. Kettle and Sellars (1996) studied the development of third- year teaching students. They analysed the students' reflective writings and interviewed them extensively about their reflective practices. They found that the use of peer reflective groups encouraged student teachers to challenge existing theories and their own preconceived views of teaching while modelling for them a collaborative style of professional development that would be useful throughout their teaching careers (Kettle and Sellars, 1996). At the level of in-service teaching, studies have shown that 
critical reflection upon experience continues to be an effective technique for professional development. Therefore, effective teacher professional development should involve more than occasional large-group sessions; it should include activities such as study teams and peer coaching in which teachers continuously examine their assumptions and practices.

\section{Research Aim}

The main purpose of this study was aimed to investigate the attitudes of principals, supervisors and mentees towards action research as reflective practices. Specifically, the study was intended to:

(i) Find out the attitudes of student-teachers (mentees) towards action research as reflective practices.

(ii) Pinpoint the extent at which the attitudes of school principals and supervisors affect the attitudes of mentees towards action research as reflective practices.

(iii) Identify the extent to which student-teachers (the mentees') working environments directly or indirectly affect mentees' attitude towards action research as reflective practices.

(iv) Assess the degree to which the university lecturers' methods of teaching affect the attitudes of mentees towards action research as reflective practices.

(v) Seek out the possible alternative solutions in coordination with concerned stakeholders to settle those problems related to PGDT programs to make it effective as program in general and as a profession in particular.

\section{METHOD}

Descriptive survey research design was employed to carry out this study because the very purpose of descriptive survey research design is to describe the characteristics or behaviours of a given population in a systematic and accurate fashion. Descriptive survey research design, according to Best ( in Cohen et.al, 2007), is concerned with conditions or relationships that exist; practices that prevail; beliefs, points of views, or attitudes that are held; processes that are going on; effects that are being felt; or trends that are developing. Therefore, principals, supervisors and mentees attitudes towards action research as reflective practices were surveyed and the data collected was subjected to both quantitative and qualitative analysis. The target population for this study consisted of principals, supervisors and mentees who have been working in these three clustered centres (Chiro, Haramaya and Jigjiga) regularly.

\section{Study Samples}

The samples used for this study consisted of 82 mentees and 38 school principals taken from three clustered centres (Chiro, Haramaya, and Jigjiga) by stratified random sampling whereas 26 school supervisors were taken from the three clustered centres mentioned above by employing availability sampling techniques. Stratified random sampling technique was employed to principals and mentees because firstly, there were different subdivisions in the targeted population which are important to be considered. Secondly, there were also variations in population sizes of different strata in this case 
(clustered centres, sex, ages and experiences) of the populations which were not equal in size. The primary data were collected through questionnaires from school principals, supervisors and mentees who have been working and supervised under these three clustered centres in the academic year of 2014/15. Moreover, structured observational checklist was employed to get adequate information for further evidence in this study.

\section{FINDINGS}

The data obtained from respondents were analysed using the Statistical Package for the Social Sciences (SPSS version 16). The mean score (M) was used to see the level of agreement of respondents on the attitudes of action research as a reflective practice. Accordingly, If $\mathrm{M}=1.00-1.50$, it is Strongly Disagree; if $\mathrm{M}=1.50-2.50$, it is Disagree; if $\mathrm{M}=2.50-3.50$, it is Undecided if $\mathrm{M}=3.50-4.50$, it is Agree, and if $\mathrm{M}=4.50-5.00$, it is Strongly Agree. On the other hand, the standard deviations of the score used to measure how the respondents' response deviated from the mean score. One way ANOVA statistical analysis was used to see the differences among the three groups of respondents of the three clustered centres.

Table 1

Mentees' attitude towards action research as reflective practices

\begin{tabular}{|c|c|c|c|c|c|c|c|c|c|}
\hline \multicolumn{5}{|c|}{ Descriptive Statistics } & \multicolumn{5}{|c|}{ Summary of ANOVA } \\
\hline Items & $G M$ & $S D$ & $S V$ & & $S S$ & $d f$ & $M S$ & $F$ & Sig \\
\hline Chiro & & & Between Groups & 33.19 & & 2 & 16.55 & 9.51 & 0.01 \\
\hline Cluster & 3.54 & 1.52 & Within Groups & 137.46 & & 79 & 1.74 & & \\
\hline Center & & & Total & 170.65 & & 81 & & & \\
\hline Haramay & & & Between Groups & 16.48 & & 2 & 8.24 & 2.96 & 0.06 \\
\hline a Cluster & 3.55 & 1.39 & Within Groups & 219.62 & & 79 & 2.78 & & \\
\hline Center- & & & Total & 236.10 & & 81 & & & \\
\hline Jigjiga & & & Between Groups & 6.29 & & 2 & 3.19 & 1.19 & 0.60 \\
\hline Cluster & 3.68 & 1.51 & Within Groups & 212.51 & & 79 & 2.69 & & \\
\hline Center & & & Total & 218.80 & & 81 & & & \\
\hline
\end{tabular}

The data summarized in the table1 clearly reveals that the calculated mean score of the respondents of each clustered centre respectively were $3.54,3.55$ and 3.68 . This shows us that almost all of them were agreed on lack of interest, lack of adequate knowledge, extreme dependence on theory and inadequate teaching skills from university PGDT lecturers and poor status of student-teachers towards action research as reflective practices were drained from them in poor motivation and poor attitudes. Furthermore, the obtained standard deviations from the three clustered centres were 1.52, 1.39 and1.51 which respectively were showed us that there was a little dispersion among mentees from Chiro and Haramaya, and between Haramaya and Jigjiga even though there was no much dispersion between Chiro and Jigjiga. On the other hand, the computed F ratio at $\alpha=0.05, \mathrm{~F}(2,79)=9.51$ in the case of Chiro clustered centre exceeds the critical region at $\alpha=0.05, \mathrm{~F}(2,79)=3.11)$. So, it was found that there was statistically a significant mean difference among mentees on the parameters of attitudes towards action research as reflective practices, $\mathrm{F}(2,79)=9.51, \mathrm{p}<0.05$, one tailed. On the contrary, the computed $\mathrm{F}$ at $\alpha=0.05, \mathrm{~F}(2,79)=2.96$ and $\mathrm{F}(2,79)=1.19$ in case of 
both Haramaya and Jigjiga clustered centres were less than the critical region at $\alpha=$ $0.05, \mathrm{~F}(2,79)=3.11)$. Therefore, it was found that there were no statistically significance mean differences among mentees in lack of interest, lack of adequate knowledge, extreme dependence on theory and inadequate teaching skills from university PGDT lecturers and poor status of student-teachers ttowards action research as reflective practices, $F(2,79)=2.96$, and $F(2,79)=1.19 p>0.05$, one tailed. Moreover, the structured observational checklists showed that almost the same evidence was observed except the difference existed on lack of instructional materials and references.

Table 2

Mentees' attitudes towards the influence of Lecturers Methodology in teaching action research as reflective practices is shown below

\begin{tabular}{|c|c|c|c|c|c|c|c|c|}
\hline \multicolumn{3}{|c|}{ Descriptive Statistics } & \multicolumn{6}{|c|}{ Summary of ANOVA } \\
\hline Items & $M$ & $S D$ & $S V$ & SS & $d f$ & $M S$ & $F$ & Sig \\
\hline Haramaya & & & Between Groups & 26.81 & 2 & 13.41 & 7.98 & 0.00 \\
\hline Clustered & 2.97 & 1.45 & Within Groups & 132.72 & 79 & 1.68 & & \\
\hline Center & & & Total & 159.53 & 81 & & & \\
\hline Chiro & & & Between Groups & 8.48 & 2 & 4.24 & 1.70 & 0.31 \\
\hline Clustered & 3.11 & 1.57 & Within Groups & 158.00 & 79 & 2.50 & & \\
\hline Center & & & Total & 369.13 & 81 & & & \\
\hline Jigjiga & & & Between Groups & 0.74 & 2 & 0.37 & 0.36 & 0.99 \\
\hline Clustered & 3.26 & 1.58 & Within Groups & 80.58 & 79 & 1.02 & & \\
\hline Center & & & Total & 81.32 & 81 & & & \\
\hline
\end{tabular}

The summarized data in the table 2 clearly reveals that the computed mean score of the respondents of each centres were respectively $2.97,3.11$ and 3.26 which were shown us that almost all of them were undecided on large number of mentees per class, lack of innovative in methodology, lack of instructional materials, inadequate supervision of the inspectors in secondary schools, and lack of dedication from lecturers did not bring anything different among them as far as the attitudes of action research as reflective practices was concerned. In additions, the obtained standard deviations of the three clustered centres respectively were $1.46,1.57$ and 1.57 . This shows us that there were no much consistency existingamong the three clustered centres on those parameters.

On the other hand, the calculated F at $\alpha=0.05, \mathrm{~F}(2,79)=5.38$ in case of Haramaya clustered centre exceeds the critical region at $\alpha=0.05, \mathrm{~F}(2,79)=3.11$. Hence, one can conclude that there was statistically a significance mean difference among mentees' attitudes towards action research as reflective practices, $\mathrm{F}(2,79)=5.38, \mathrm{p}<0.05$, one tailed. On the other hand, the calculated F at $\alpha=0.05, \mathrm{~F}(2,79)=1.70$ and $\mathrm{F}(2,79)=$ 1.42 in both Jigjiga and Chiro clustered centres respectively were less than the critical region $\mathrm{F}$ at $\alpha=0.05, \mathrm{~F}(2,79)=3.11$. Hence, it could be concluded that there were no statistically significant mean differences among mentees' attitudes towards action research as reflective practices, $\mathrm{F}(2,79)=1.70$ and $\mathrm{F}(2,79)=1.42, \mathrm{p}>0.05$, one tailed respectively. Moreover, the structured observational checklists showed that almost the same evidence was observed except the difference existed on lack of instructional materials and methodology. 
Table 3

Environmental factors on mentees' attitude towards Action Research as reflective practices

\begin{tabular}{|c|c|c|c|c|c|c|c|c|}
\hline \multicolumn{3}{|c|}{ Descriptive Statistics } & \multicolumn{6}{|c|}{ Summary of ANOVA } \\
\hline Items & M & $S D$ & $S V$ & $S S$ & $d f$ & $M S$ & $F$ & Sig. \\
\hline Chiro & & & Between Groups & 6.70 & 2 & 3.35 & 1.36 & 0.10 \\
\hline Clustered & 3.60 & 1.40 & Within Groups & 195.13 & 79 & 2.47 & & \\
\hline Centers & & & Total & 201.83 & 81 & & & \\
\hline Haramaya & & & Between Groups & 2.03 & 2 & 1.05 & 0.50 & 0.67 \\
\hline Clustered & 3.76 & 1.16 & Within Groups & 164.32 & 79 & 2.08 & & \\
\hline Center & & & Total & 166.35 & 81 & & & \\
\hline Jigjiga & & & Between Groups & 5.52 & 2 & 2.76 & 1.47 & 0.30 \\
\hline Clustered & 3.86 & 1.50 & Within Groups & 148.52 & 79 & 1.88 & & \\
\hline Centers & & & Total & 154.04 & 81 & & & \\
\hline
\end{tabular}

From the table 3, it can be seen that the computed mean scores for the three cluster centres (Chiro, Haramaya and Jigjiga) were 3.60, 3.76 and 3.86, respectively. This indicates that condition that the entire three cluster centres 'mentees were agreed on the five environmental factors (personal attributes, system requirements, pedagogical knowledge, modelling and feedback) had a negative impact on mentees' attitudes towards action research as reflective practices. Moreover, the computed standard deviation of the threeclustered centres mentioned above were $1.40,1.16$ and 1.50 , respectively..These also indicated that the majority of mentees were agreed on the five environmental factors affecting their attitudes towards action research as reflective practices even though there were variability among each group. Moreover, the obtained $\mathrm{F}$ ratio at $\alpha=0.05, \mathrm{~F}(2,79)=$ 1.36), $\mathrm{F}(2,79)=0.50$ and $\mathrm{F}(2,793)=1.47$ in all the three clustered centres were much less than the critical region at $\alpha=0.05, \mathrm{~F}(2,79)=3.11$. Hence, it could be concluded that there were no statistically significant mean differences among mentees on these five environmental factors affecting their attitudes towards action research as reflective practices, $\mathrm{F}(2,79)=1.36), \mathrm{F}(2,79)=0.50$ and $\mathrm{F}(2,79)=1.47, \mathrm{p}>0.05$, one tailed respectively. Moreover, the structured observational checklists obtained during supervisions and reflective sessions indicated that these five environmental factors had been proven in affecting mentees' attitudes towards action research as reflective practices.

Table 4

School principals' and supervisors' "Personal Attributes" towards action research as reflective practicec

\begin{tabular}{|c|c|c|c|c|c|c|c|c|}
\hline \multicolumn{3}{|c|}{ Descriptive Statistics } & \multicolumn{6}{|c|}{ Summary of ANOVA } \\
\hline Items & $M$ & $S D$ & $S V$ & SS & $d f$ & $M S$ & $F$ & Sig. \\
\hline Chiro & & & Between Groups & 3.94 & 2 & 1.97 & 0.99 & 0.55 \\
\hline Clustered & 4.06 & 1.16 & Within Groups & 121.39 & 61 & 1.99 & & \\
\hline Centers & & & Total & 125.33 & 63 & & & \\
\hline Haramaya & & & Between Groups & 5.73 & 2 & 2.87 & 1.49 & 0.37 \\
\hline Clustered & 4.21 & 1.14 & Within Groups & 117.12 & 61 & 1.92 & & \\
\hline Center & & & Total & 122.85 & 63 & & & \\
\hline Jigjiga- & & & Between Groups & 5.86 & 2 & 2.93 & 1.75 & 0.30 \\
\hline Clustered & 4.25 & 1.08 & Within Groups & 241.45 & 61 & 1.67 & & \\
\hline Centers & & & Total & 101.87 & 63 & & & \\
\hline
\end{tabular}


From the data in table 4, it is apparent that the computed mean scores for the three cluster centres (Chiro, Haramaya and Jigjiga) were 4.06, 4.21 and 4.25, respectively. This indicates that the school principals and supervisors in all three clustered centreswere agreed on the fact that five personal attributes (listening attentively, comforting in talking, supporting, assisting in reflecting and instilling confidence) had an impact on mentees' attitudes towards action research as reflective practices. Besides, the computed standard deviations of the three clustered centres mentioned above were $1.16,1.14$ and 1.04, respectively. These indicated that the majority of the school principals and supervisors were agreed on "personal attributes" towards action research as reflective practices even though there was variability among groups. On the other hand, the obtained $\mathrm{F}$ ratio at $\alpha=0.05, \mathrm{~F}(2,61)=0.99, \mathrm{~F}(2,61)=1.49$ and $\mathrm{F}(2,61)=$ 1.75 in all the three clustered centres were very much less than the critical region at $\alpha=$ $0.05, F(2,61)=3.15$. Hence, it could be concluded that there were no statistically significant mean differences among school principals and supervisors on personal attributes towards action research as reflective practices, $\mathrm{F}(2,61)=0.99, \mathrm{~F}(2,61)=$ 1.49 and $\mathrm{F}(2,61)=1.75, \mathrm{p}>0.05$, one tailed respectively. Moreover, the structured observational checklists during supervisions and reflection sessions proving the above findings were held the same.

Table 5

School principals and supervisors' "System Requirements" towards action research

\begin{tabular}{|c|c|c|c|c|c|c|c|c|}
\hline \multicolumn{3}{|c|}{ Descriptive Statistics } & & \multicolumn{5}{|c|}{ Summary of ANOVA } \\
\hline Items & $M$ & $S D$ & $S V$ & $S S$ & $d f$ & $M S$ & $F$ & Sig. \\
\hline Chiro & \multirow{3}{*}{3.96} & \multirow{3}{*}{0.95} & Between Groups & 0.07 & 2 & 0.04 & \multirow[t]{3}{*}{0.27} & \multirow[t]{3}{*}{0.99} \\
\hline Clustered & & & Within Groups & 9.15 & 61 & 0.15 & & \\
\hline Center & & & Total & 9.22 & 63 & & & \\
\hline Haramaya & \multirow{3}{*}{4.00} & \multirow{3}{*}{1.26} & Between Groups & 4.84 & 2 & 2.42 & \multirow[t]{3}{*}{1.96} & \multirow[t]{3}{*}{0.36} \\
\hline Clustered & & & Within Groups & 137.25 & 61 & 2.25 & & \\
\hline Center & & & Total & 142.09 & 63 & & & \\
\hline Jigjiga- & \multirow{3}{*}{4.22} & \multirow{3}{*}{1.07} & Between Groups & 0.49 & 2 & 0.25 & \multirow[t]{3}{*}{0.25} & \multirow[t]{3}{*}{0.98} \\
\hline Clustered & & & Within Groups & 61.00 & 61 & 1.00 & & \\
\hline Center & & & Total & 61.49 & 63 & & & \\
\hline
\end{tabular}

As it was indicated in the table 5, the g mean scores for the three clustered centres (Chiro, Haramaya and Jigjiga respectively) were 3.96, 4.00 and 4.22. This indicates that the three clustered centers' principals and supervisors were agreed on the fact that three system requirements (discussing aims, discussing policies and outlining curriculum) had an impact on mentees' attitudes towards action research as reflective practices. Moreover, the computed standard deviations of the three clustered centres mentioned above respectively were $0.95,1.26$ and 1.07 . Moreover, the obtained $\mathrm{F}$ ratio at $\alpha=0.05$, $\mathrm{F}(2,61)=0.27), \mathrm{F}(2,61)=1.96$ and $\mathrm{F}(2,61)=0.25$ in all the three clustered canters were very much less than the critical region at $\alpha=0.05$, F $(3,61)=3.15)$. Hence, it could be concluded that there were no statistically significant mean differences among school principals and supervisors on system requirements on mentees' attitudes towards action research as reflective practices, $\mathrm{F}(2,61)=0.27), \mathrm{F}(2,61)=1.96$ and $\mathrm{F}(2,61)=$ 
$0.25, \mathrm{p}>0.05$, one tailed respectively. However, the structured observations checklists during supervisions and reflection sessions disproved the above findings.

Table 6

School Principals' and Supervisors' on "Pedagogical Knowledge" towards action research

\begin{tabular}{|c|c|c|c|c|c|c|c|c|}
\hline \multicolumn{3}{|c|}{ Descriptive Statistics } & \multicolumn{6}{|c|}{ Summary of ANOVA } \\
\hline Items & $M$ & $S D$ & $S V$ & SS & $d f$ & $M S$ & $F$ & Sig \\
\hline \multirow{3}{*}{$\begin{array}{l}\text { Jigjiga Clustered } \\
\text { Center }\end{array}$} & \multirow{3}{*}{4.16} & \multirow{3}{*}{1.21} & Between Groups & 4.38 & 2 & 2.19 & \multirow[t]{3}{*}{1.87} & \multirow[t]{3}{*}{0.30} \\
\hline & & & Within Groups & 71.37 & 61 & 1.17 & & \\
\hline & & & Total & 75.83 & 63 & & & \\
\hline \multirow{3}{*}{$\begin{array}{l}\text { Chiro, Clustered } \\
\text { Center }\end{array}$} & \multirow{3}{*}{4.16} & \multirow{3}{*}{1.03} & Between Groups & 4.14 & 2 & 2.07 & \multirow[t]{3}{*}{1.62} & \multirow[t]{3}{*}{0.38} \\
\hline & & & Within Groups & 78.08 & 61 & 1.28 & & \\
\hline & & & Total & 82.22 & 63 & & & \\
\hline & & & Between Groups & 0.97 & 2 & 0.49 & 0.5 & 0.86 \\
\hline Haramaya & 4.29 & 0.91 & Within Groups & 59.78 & 61 & 0.98 & & \\
\hline Clustered Center & & & Total & 60.75 & 63 & & & \\
\hline
\end{tabular}

From the table 6 , it can be seen that the computed mean scores for the three clustered centres (Jigjiga, Chiro and Haramaya) were 4.16, 4.16 and 4.29, respectively.. This indicates that the school principals and supervisors in all three clustered centres were agreed on the fact that eleven practices of pedagogical knowledge (providing viewpoints, discussing problem solving, guiding preparation, discussing assessment, assisting with teaching strategies, discussing content knowledge, assisting with classroom management, discussing questioning techniques, discussing implementation, assisting in planning, and assisting with time tabling) had a negative impact on mentees' attitudes towards action research as reflective practices. Moreover, the computed standard deviations of the three clustered centres mentioned above were 1.21, 1.03 and 0.91 , respectively. . Besides, the obtained $\mathrm{F}$ ratio at $\alpha=0.05, \mathrm{~F}(2,61)=1.87), \mathrm{F}(2,61)$ $=1.62$ and $\mathrm{F}(2,61)=0.50$ in all the three clustered canters were very much less than the critical region at $\alpha=0.05, \mathrm{~F}(2,61)=3.15)$. Hence, it could be concluded that there were no statistically significant mean differences among school principals and supervisors on pedagogical knowledge on mentees' attitude towards action research as reflective practices, $\mathrm{F}(2,61)=1.87), \mathrm{F}(2,61)=1.62$ and $\mathrm{F}(2,61)=0.50, \mathrm{p}>0.05$, one tailed respectively. Moreover, the structured observations checklists conducted during supervisions and reflection sessions supported the above findings. 
Table 7

School principals' and supervisors' opinions on "Modelling" towards action research as reflective practices

\begin{tabular}{|c|c|c|c|c|c|c|c|c|}
\hline \multicolumn{3}{|c|}{ Descriptive Statistics } & \multicolumn{6}{|c|}{ ANOVA Summary Table } \\
\hline Items & $M$ & $S D$ & $S V$ & $S S$ & $d f$ & $M S$ & $F$ & Sig \\
\hline Chiro & \multirow{3}{*}{3.55} & \multirow{3}{*}{1.05} & Between Groups & 5.04 & 2 & 2.52 & \multirow[t]{3}{*}{2.03} & \multirow[t]{3}{*}{0.12} \\
\hline Clustered & & & Within Groups & 75.64 & 61 & 1.24 & & \\
\hline Center & & & Total & 80.68 & 63 & & & \\
\hline Haramaya & \multirow{3}{*}{3.60} & \multirow{3}{*}{1.11} & Between Groups & 4.09 & 2 & 2.05 & \multirow[t]{3}{*}{1.49} & \multirow[t]{3}{*}{0.18} \\
\hline Clustered & & & Within Groups & 84.18 & 61 & 1.38 & & \\
\hline Center & & & Total & 88.29 & 63 & & & \\
\hline Jigjiga- & \multirow{3}{*}{3.74} & \multirow{3}{*}{1.25} & Between Groups & 5.19 & 2 & 2.59 & \multirow[t]{3}{*}{1.18} & \multirow[t]{3}{*}{0.37} \\
\hline Clustered & & & Within Groups & 133.59 & 61 & 2.19 & & \\
\hline Center & & & Total & 138.78 & 63 & & & \\
\hline
\end{tabular}

As it can be understood from table 7, the computed mean scores for the three clustered centres (Chiro, Haramaya and Jigjiga) were 3.55, 3.60 and 3.74, respectively.. This indicates that all the three clustered centers' school principals and supervisors were agreed on the idea that eight practices of modelling (demonstrating hands-on activities, displaying enthusiasm for teaching, modelling a well-designing lesson, modelling effective teaching, modelling teaching, modelling rapport with students, using syllabus language, and modelling classroom management) were found to have a negative impact on mentees' attitudes towards action research as reflective practices. Furthermore, the computed standard deviations of the three clustered canters mentioned above were 1.05, 1.11 and 1.25 , respectively.. On the other hand, the obtained, F ratio at $\alpha=0.05, \mathrm{~F}(2$, $61)=2.03, \mathrm{~F}(2,61)=1.49$ and $\mathrm{F}(2,61)=1.18$ in all the three clustered canters were very much less than the critical region at $\alpha=0.05, \mathrm{~F}(2,61)=3.15$. Hence, it was concluded that there were no statistically significant mean differences among school principals and supervisors on modelling towards action research as reflective practices, $(2,61)=2.03, \mathrm{~F}(2,61)=1.49$ and $\mathrm{F}(2,61)=1.18, \mathrm{p}>0.05$, one tailed respectively. Moreover, the structured observational checklists conducted during supervision and reflective sessions proved that these issues were very important for mentees even though the reality were different from what was going in the actual sense. 
Table 8

School principals' and supervisors' ideas on "Providing Feedback" towards action research as a reflective practices

\begin{tabular}{|c|c|c|c|c|c|c|c|c|}
\hline \multicolumn{3}{|c|}{ Descriptive Statistics } & \multicolumn{6}{|c|}{ ANOVA Summary Table } \\
\hline Items & $M$ & $S D$ & $S V$ & $S S$ & $d f$ & $M S$ & $F$ & Sig \\
\hline Jigjiga & \multirow{3}{*}{3.53} & \multirow{3}{*}{1.25} & Between Groups & 1.40 & 2 & 0.70 & \multirow{3}{*}{0.35} & \multirow[t]{3}{*}{0.92} \\
\hline Clustered & & & Within Groups & 123.22 & 61 & 2.02 & & \\
\hline Center & & & Total & 124.62 & 63 & & & \\
\hline Chiro & \multirow{3}{*}{3.54} & \multirow{3}{*}{1.14} & Between Groups & 4.03 & 2 & 2.02 & \multirow[t]{3}{*}{1.51} & \multirow[t]{3}{*}{0.38} \\
\hline Clustered & & & Within Groups & 81.74 & 61 & 1.34 & & \\
\hline Center & & & Total & 85.77 & 63 & & & \\
\hline Haramaya & \multirow{3}{*}{3.57} & \multirow{3}{*}{1.17} & Between Groups & 3.76 & 2 & 1.88 & \multirow[t]{3}{*}{1.31} & \multirow[t]{3}{*}{0.55} \\
\hline Clustered & & & Within Groups & 87.84 & 61 & 1.44 & & \\
\hline Center & & & Total & 91.60 & 63 & & & \\
\hline
\end{tabular}

As it was indicated in table 9, the computed mean scores for the three clustered centres (Jigjiga, Chiro and Haramaya) were 3.53, 3.54 and 3.57, respectively. . This indicated that the school principals and supervisors of all the three clustered centers'were agreed on the idea that providing six "feedback" practices (providing evaluation on teaching, reviewing lesson plans, providing oral feedback, providing written feedback, articulating expectations and observing teaching to mentees) were found to be a negative impact on mentees' attitudes towards action research as reflective practices. Besides, the computed standard deviations of the three clustered centres mentioned above were $1.25,1.14$ and 1.17 , respectively.. On the other hand, the computed $\mathrm{F}$ ratio at $\alpha=0.05, \mathrm{~F}(2,61)=$ $0.35), F(2,61)=1.51$ and $F(2,61)=1.31$ in all the three clustered centres were respectively very much less than the critical region at $\alpha=0.05, \mathrm{~F}(2,61)=3.15$. Hence, it was concluded that there were no statistically significant mean differences among school principals and supervisors ideas on providing feedback to mentees' attitude towards action research as reflective practices, $\mathrm{F}(2,61)=0.35), \mathrm{F}(2,61)=1.51$ and $\mathrm{F}$ $(2,61)=1.31$, one tailed respectively. In addition to these statistical finding, the structured observational checklists conducted during the supervision and reflective sessions proved that these issues were very important for the mentees even though the reality were different from what was going on in the actual situations.

\section{DISCUSSION}

This study attempts to investigate the Attitude of School Principals, Supervisors and Mentees towards Action Research as a Reflective Practices with particular reference to Eastern Ethiopian Post Graduate Diploma in Secondary School Teaching (PGDT). One interesting finding of this study was that all mentees were agreed on the lack of interest, the lack of adequate knowledge, the extreme dependence on theory and the inadequate teaching skills from university PGDT lecturers and poor status of mentees-themselves towards action research as reflective practices. On the other hand, the finding of the same study was found that almost all of the respondents were undecided on large number of mentees per class, the lack of innovative in methodology, the lack of 
instructional materials, the inadequate supervision of the inspectors in secondary schools, and the lack of dedication from lecturers did not bring anything different among them as far as the attitudes of action research as reflective practices was concerned. The second interesting finding was that the entire three cluster centres 'mentees were agreed on idea that the five environmental factors (personal attributes, system requirements, pedagogical knowledge, modelling and feedback) had a negative impact on mentees' attitudes towards action research as reflective practices.

The third interesting finding was that $\mathrm{t}$ the school principals and supervisors in the entire three clustered centres were agreed on the idea that five personal attributes (listening attentively, comforting in talking, supporting, assisting in reflecting and instilling confidence) had a negative impact on mentees' attitudes towards action research as reflective practices. Moreover, the one way ANOVA analysis was indicated that there were no statistically significant mean differences among the respondents. The fourth interesting finding in this study was that the three clustered centers' principals and supervisors were agreed on the idea that the three systems' requirements (discussing aims, discussing policies and outlining curriculum) had an impact on mentees' attitudes towards action research as reflective practices.

Furthermore, it was found that there were no statistically significant mean differences among the three centres on three system requirements (discussing aims, discussing policies and outlining curriculum). The fifth interesting finding in the same study was that the school principals and supervisors of the three clustered centres were agreed on the idea that eleven practices of pedagogical knowledge (providing viewpoints, discussing problem solving, guiding preparation, discussing assessment, assisting with teaching strategies, discussing content knowledge, assisting with classroom management, discussing questioning techniques, discussing implementation, assisting in planning, and assisting with time tabling) had a negative impact on mentees' attitudes towards action research as reflective practices. Moreover, one way ANOVA analysis was shown us that there were no statistically significant mean difference among school principals and school supervisors on these variables. These indicated that the variables have been negatively affected the mentees' attitudes towards action research as reflective practices.

The sixth interesting finding in the same study was that the school principals and supervisors of all the three clustered centers were agreed on the idea that the seven practices of modelling (demonstrating hands-on activities, displaying enthusiasm for teaching, modelling a well-designing lesson, modelling effective teaching, modelling rapport with students, using syllabus language, and modelling classroom management) were found to have a negative impact on mentees' attitudes towards action research as reflective practices. Moreover it was found that there were no statistically significant mean differences among the three groups in the three clustered centres on these variables. Finally, another important finding was that all the three clustered centers' school principals and supervisors were agreed on the idea that providing feedback practices (providing evaluation on teaching, reviewing lesson plans, providing oral feedback, providing written feedback, articulating expectations and observing teaching 
to mentees) were found to be a negative impact on mentees' attitudes towards action research as reflective practices. Furthermore, there were no statistically significant mean differences among the three centres on these variables.

The finding of this study is also supported by the study carried out by Sharpe (2004) who found that the concept of action research as reflective practices regarded the teacher as a moral agent and an informed, knowledgeable practitioner. The distinctive nature of professional knowledge lies in the interplay between its construction and use. When teachers use their knowledge, use changes what that knowledge is.

\section{Implications of the study}

The impact of this study proved that attitude of school principals, supervisors and mentees towards action research as reflective practices had a negative impact on teaching learning processes in schools. Teachers as action researcher and practitioners apply the rigors of scientific inquiry in the context of their classroom and classroom experience in attempt to improve teaching effectiveness. Because action research as reflective practices is conducted by classroom teachers, it services as a vehicle through which teachers investigate issues of interest and then incorporate the result into their own planning and future teaching.

There are only few studies conducted in Ethiopia that relates to the attitudes of principals, supervisors and mentees towards action research as reflective practices. Thus, based on the findings, it is an evident that action research as reflective practices has been found to serve not only as a means of improving teaching but also in developing practitioners' flexibility and problem solving skills and their attitudes to professional development and the process of change. Therefore, it is recommended that participations in action research as reflective practices is resulted in increased confidence, self esteem, willingness to embrace and liberated creative potential for teacher educators.

\section{Limitation and Recommended Future Studies}

For future studies, it is recommended that larger samples should be included in the study areas. By using larger populations such as by including all secondary schools found in Eastern Ethiopian from Harari and Dire Dewa City Administration, the research result can be generalized across Eastern Ethiopian Secondary Schools. As such, the attitudes of school principals, supervisors and mentees towards action research as reflective practices for the pilgrimage topic can be promoted if the findings of the future study are similar to this study.

Future studies are also recommended to look at the selection of students by taking into account the differences extended beyond the expected, such as socioeconomic backgrounds that may influence these studies as the descriptive survey research design used in this study had used existing class, assuming that the three clustered centres are similar. Location of schools such as rural schools and urban located school might contribute to different result for the study. Furthermore the study is limited only to the topic of the attitudes of school principals, supervisors and mentees towards action 
research as reflective practices. Thus, it is suggested that the same study should be expanded and applied to topics and other places of worship.

\section{CONCLUSIONS}

This study found that the attitude of principals, supervisors and mentees towards action research as reflective practices has had a negative impact on teaching profession in general and mentees (student teachers) in particular. The reason is that school principals, supervisors and mentees have developed negative attitudes towards action research as reflective practices. They have never understood that action research as reflective practices were used to provide a vehicle for improving teacher's decision making and increasing teacher effectiveness and for encouraging professional practices. Moreover, school principals and supervisors have failed to understand that action research as reflective practices are used to (1) be a tool for individual teacher focusing on changes within her/ his classroom, (2) be an approach employed by a research team of teachers addressing a problem that extends across the classroom, and (3) be a facilitative approach to school wide or district wide problems. Therefore, school principals and supervisors need to provide supporting, encouraging and motivating mentees (studentteachers) so as to attract them in the profession of teaching. Whenever these stakeholders develop positive attitudes towards action research as reflective practices, they can bring the necessary changes that the country will expect them to bring changes in its next quality generation.

\section{REFERENCES}

Boud, D. \& Walker, D. (1998). Promoting reflection in professional courses: The challenge of context. Studies in Higher Education, 23(2), 191-206. EJ 570398.

Clift, R.T., Houston, W.R., \& Pugach, M.C., eds. (1990). Encouraging reflective practice in education: An analysis of issues and programs. New York: Teachers College Press.

Cohen L., Manion L. and Morrison L. (2007). Research methods in education. NY: 270 Madison Avenue.

Erickson, G. and Mackinnon, A. (1991). 'Seeing classrooms in new ways: On becoming a science teacher'The Reflective Turn: Case Studies In and On Educational experience in an initial teacher education course', Journal of Education for Teaching, 15, (1), pp.342-355.Gemechu, A. (2014). Teachers' Perceptions in Teaching Large Class Sizes in Eastern Ethiopian Higher Learning Institutions. Journal of Education and Practices. 5 (4): 76-75

Grimmet, P. and Crehan, E.P. (1990). Conditions Which Facilitate and Inhibit Teacher Reflection in Clinical Supervision: Collegiality Re-Examined, Paper presented at the annual meeting of the American Educational Research Association, Boston..

Hopkins, C. D., \& Antes, R.L. (1990). Educational research: A structure for inquiry (3rd Ed). Itasca, IL: F.E. Peacock. 
Kettle B., \& Sellars, N. (1996). The development of student teachers practical theory of teaching. Teaching and Teacher Education, 12(1), 1- 24. EJ 52- 79.

La Boskey, V.K. (1990). Reflectivity in Preservice Teachers: Alert Novices vs. Common sense Thinkers, paper presented at the annual meeting of the American Educational Research Association, Boston.

Russell, T. and Munby, H. (1991). 'Reframing: The role of experience in developing teachers' professional knowledge', The Reflective Turn: Case Studies In and On Educational Practice, New York, Teachers College Press, pp. 164-88.

Sharpe, R. (2004). How do Professionals Learn and Develop? Implications for Staff and Education Developers. Teacher Education, Detroit, MI.

Teshome, A. 2001. The impact of assessment on quality education. AAU: AAU Press.

Schuck, C. and Wood, J. (2006). Playing, reflecting, and reality. Journal of Holistic Healthcare, 34 (3) British Holistic Medical Association.

Valli, L. (1992). 'Introduction', in VALLI, L. (Ed). Reflective Teacher Education: Cases and Critiques. Albany: Suny Press.

Watts, H. (1985). When teachers are researchers, teaching improves learners. River, New Jersey: Pearson Merill Prentice-Hall.

Zeichner, K. (1987) 'Preparing reflective teachers'. International Journal of Educational Research, 11 (5): 565-75.

\section{Turkish Abstract}

Okul Müdürlerinin, Müdür Yardımcılarının ve Öğrencilerin Yansıtıcı Düşünce Yöntemine Yönelik Eylem Araştırmasına Karşı Tutumları

$\mathrm{Bu}$ çalışmanın amacı uzaktan eğitimde (PGDT) müdürlerin, müdür yardımcılarının ve öğrencilerin yansıtıcı düşünce yöntemine yönelik eylem araştırmasına karşı tutumlarını incelemektir. $\mathrm{Bu}$ çalışmada 3 tane birbirine yakın merkezden tabakalı rastgele örnekleme yöntemine göre alınan 82 öğrenci, 38 müdür ve 26 amir kullanılmıştır. Araştırmacı, verilerin yorumlanması ve örneklemin karakteristiğini tanımlamak için betimleyici istatistik (standart sapma ve ortalama değer) kullanmıştır. Buna ek olarak olası değişkenlerin olduğu gruplar içindeki ve gruplar arasındaki anlamlı farklılığı karşılaştırmak için de çıkarımsal istatistik yöntemi (tek yönlü ANOVA) tercih edilmiştir. Bu çalışmanın bulguları, Haramaya Kampüsündeki yaratıcı yöntemlerden, eğitici araç - gereçlerden ve uzman eğitimcilerden yoksun öğrencilerin yansıtıcı düşünce yöntemine yönelik eylem araştırmasına karşı tutumlarında istatistiksel olarak anlamlı bir farklılık olduğunu göstermiştir. Bu yüzden müdürler ve müdür yardımcıları gibi sistem uygulayıcılarının ulusun ihtiyacı olan, Etiyopyalı çocukların eğitim kalitesini arttırmak ve davranış değişikliklerini sağlama konusunda ahlaklı, pratik, profesyonel, sorumluluk sahibi ve eleştirel davranması gerekmektedir.

Anahtar Kelimeler: tutum, Haramaya Üniversitesi, psikoloji, Etiyopyalı çocuklar, okul müdürleri, yansitıcı ögretim 


\section{French Abstract \\ Attitude de Principaux Scolaires, Superviseurs et Mentees vers Recherche d'Action comme Pratiques Réfléchissantes}

Cette étude a été visée pour examiner l'attitude de principaux, des superviseurs et mentees vers la recherche d'action comme des pratiques réfléchissantes(réfléchies) dans le Diplôme d'Étudiant post-licence dans le Collège d'enseignement général Enseignant (PGDT). Les échantillons utilisés pour cette étude ont consisté en 82 mentees, 38 Principaux et 26 Superviseurs pris de trois centres groupés en utilisant la technique d'échantillonnage aléatoire stratifiée pour mentees et des principaux tandis que la disponibilité échantillonnant des techniques a été employée pour des superviseurs. Pour faire paraître l'interprétation de données et au point, le chercheur a utilisé la statistique descriptive (le grand nombre moyen et des écarts-types) pour décrire la nature des données et les caractéristiques de l'échantillon. De plus, la statistique déductive (une façon) ANOVA) a été employée pour comparer des différences moyennes significatives existent entre et dans les groupes de la valeur la plus probable des variables. Les conclusions de cette étude ont révélé statistiquement la signification la différence moyenne parmi mentees en l'absence des méthodologies novatrices, le manque de matériels d'instruction et le manque de dévouement de conférenciers et des attitudes vers la recherche d'action comme des pratiques réfléchissantes dans le cas de centre groupé Haramaya. Donc, les principaux et les superviseurs de l'unité de mise en oeuvre du système devraient agir moralement, pratiquement, professionnellement, éthiquement, avec sérieux et d'une façon critique afin de satisfaire le besoin professionnel de la nation d'apporter des changements comportementaux et l'éducation de qualité pour les enfants éthiopiens.

Mots Clés: attitudes, Université Haramaya, psychologie, enfants éthiopiens, principaux scolaires, pratiques réfléchissantes

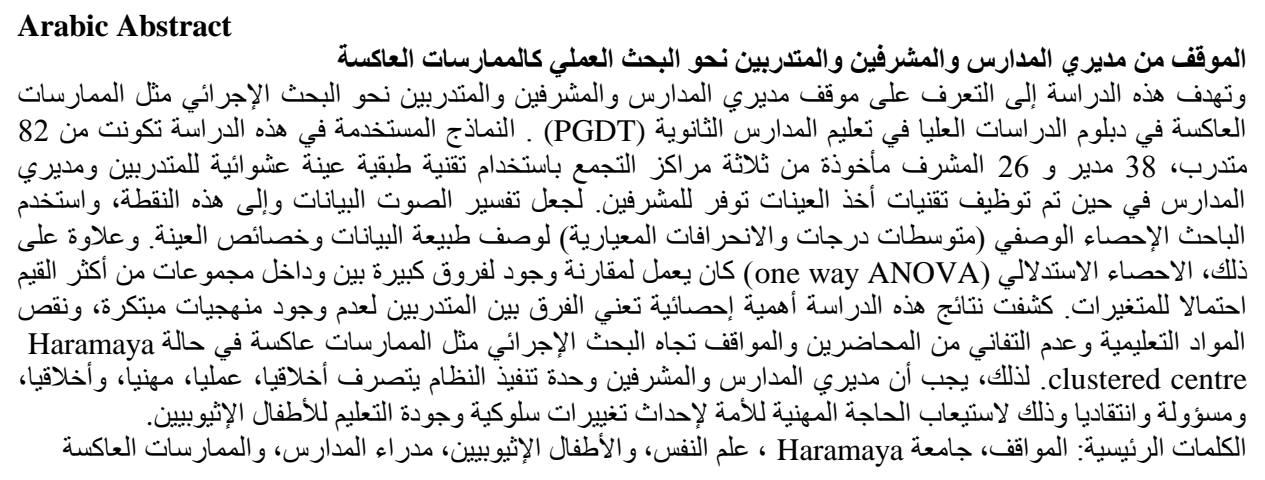




\section{German Abstract \\ Einstellung der Schulleiter, Betreuer und Mentees zur Aktionsforschung als reflektierende Praktiken}

Diese Studie zielte darauf ab, die Haltung der Principals, Supervisoren und Mentees zur Aktionsforschung als reflektierende Praktiken in Postgraduierten-Diplom in Gymnasiallehre (PGDT) zu untersuchen. Die Proben, die für diese Studie verwendet wurden, bestanden aus 82 Mentees, 38 Principals und 26 Supervisoren, die aus drei gruppierten Zentren entnommen wurden, und zwar unter Verwendung einer geschichteten Zufallsstichprobe für Mentees und Principals, während die Verfügbarkeitsprüfungstechniken für die Supervisoren verwendet wurden. Um die Interpretation von Daten-Sound und auf den Punkt, der Forscher verwendet deskriptive Statistiken (Durchschnittswerte und Standardabweichungen), um die Art der Daten und die Merkmale der Probe zu beschreiben.Darüber hinaus wurden inferentielle Statistiken (Einweg-ANOVA) verwendet, um einen signifikanten mittleren Unterschiede zwischen und innerhalb von Gruppen des wahrscheinlichsten Wertes der Variablen zu vergleichen. Die Ergebnisse dieser Studie zeigten eine statistisch signifikante mittlere Differenz zwischen Männern aus Mangel an innovativen Methoden, mangelnde Unterrichtsmaterialien und mangelnde Hingabe von Dozenten und Haltungen gegenüber Aktionsforschung als reflektierende Praktiken im Fall von Haramaya gruppierten Zentrum. Daher sollten die Prinzipien und Aufsichtsbehörden der Implementierungseinheit des Systems moralisch, praktisch, fachlich, ethisch, verantwortungsvoll und kritisch handeln, um dem professionellen Bedürfnis der Nation nachzukommen, Verhaltensänderungen und qualitativ hochwertige Bildung für die äthiopischen Kinder herbeizuführen.

Schlüsselwörter: einstellungen, Haramaya Universität, psychologie, äthiopische kinder, schulleiter, reflektierende praktiken

\section{Malaysian Abstract \\ Sikap Pengetua Sekolah, Penyelia dan Menti ke arah Kajian Tindakan sebagai Amalan Reflektif}

Kajian ini bertujuan untuk mengkaji sikap pengetua, penyelia dan menti ke arah kajian tindakan amalan reflektif dalam Diploma Lepasan Ijazah dalam Pengajaran Sekolah Menengah (PGDT). Sampel yang digunakan untuk kajian ini terdiri daripada 82 menti, 38 Pengetua dan 26 Penyelia diambil daripada tiga pusat berkelompok dengan menggunakan teknik persampelan rawak berstrata untuk murid, dan pengetua manakala ketersediaan teknik persampelan telah digunakan untuk penyelia. Bagi memudahkan penafsiran dan ketepatan data, pengkaji menggunakan statistik deskriptif (skor min dan sisihan piawai) untuk menggambarkan sifat data dan ciri-ciri sampel. Lebih-lebih lagi, statistik inferensi (sehala ANOVA) telah digunakan untuk membandingkan perbezaan min yang signifikan wujud di antara dan di dalam kumpulan yang mempunyai nilai yang paling mungkin bagi pembolehubah. Dapatan kajian ini menunjukkan terdapat perbezaan yang signifikan antara menti kerana kekurangan kaedah inovatif, kekurangan bahan-bahan pengajaran dan kekurangan dedikasi daripada pensyarah dan sikap terhadap kajian tindakan amalan reflektif dalam kes Haramaya berkelompok pusat. Oleh itu, pengetua dan penyelia unit pelaksana sistem perlu bertindak dari segi moral, praktikal, profesional, beretika, bertanggungjawab dan kritikal bagi menampung keperluan profesional negara untuk membawa perubahan tingkah laku dan pendidikan berkualiti untuk anak-anak Ethiopia.

Kata Kunci: sikap, Haramaya Universiti, psikologi, kanak-kanak Ethiopian, pengetua sekolah, amalan reflektif 


\section{Russian Abstract \\ Отношение Директоров, Замдиректоров и Тюторов Школ Исследованием Действий, Направлениым к Отражательною Практике}

Цель этого исследования расследовать отношение директоров школ, руководителей и наставляемые к исследованием действий в качестве отражательной практики в Дипломох Аспиранта в Средней Школе Преподавания (PGDT). Образцы, используемые для этого исследования состояли из 82 тюторов, 38 Принципов и 26 контролеров, взятых из трех кластерный центров с использованием стратифицированной случайной выборки для техники тюторов и директоров школ, в то время как техники выборки доступности был трудоустроена для замдиректоров. Чтобы сделать интерпретацию данных звуков и до точки, исследователь использует описательную статистику (средние оценки и стандартные отклонения), чтобы описать природу данных и характеристик образца. Кроме того, выведенная статистика (в одну сторону ANOVA) которые сравнивай различия, существуют между и внутри групп наиболее вероятного значения переменных. Выводы из данного исследования показалы статистическую значимость средней разницы у тюторов приотсутствие инновационных методологий, отсутствии материалов обучения и отсутствие преданности преподавателей и отношение в направлении к исследованию действия в отражательной практике в корпусе Haramaya. Поэтому, директоры и замдиректоры реализующего звена системы должны действовать морально, практически, профессионально, с этической точки зрения, ответственно и критически, с тем чтобы приспособить профессиональные потребности нации, чтобы принести изменения в поведение и датькачественное образование эфиопским детям.

Ключевые Слова: отношение, Haramaya университет, психология, эфиопские дети, директора школ, отражательная практика 